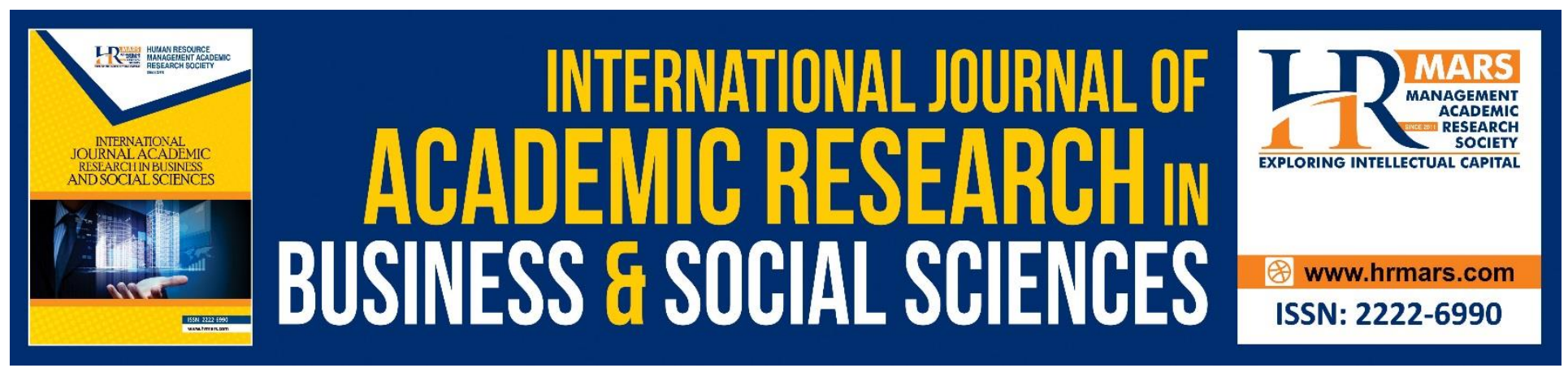

\title{
Evaluating Level of Understanding in Calculus Foundation Course (Smn3013) among Bachelor of Mathematics Education Students
}

Siti Rahaimah Ali, Nor' ain Tajudin, Nur Amalina Ahmad and Norazlin Mohd Rusdin

To Link this Article: http://dx.doi.org/10.6007/IJARBSS/v8-i10/5302

DOI: $10.6007 /$ IJARBSS/v8-i10/5302

Received: 23 Sept 2018, Revised: 17 Oct 2018, Accepted: 26 Oct 2018

Published Online: 06 Nov 2018

In-Text Citation: (Ali, Tajudin, Ahmad, \& Rusdin, 2018)

To Cite this Article: Ali, S. R., Tajudin, N., Ahmad, N. A., \& Rusdin, N. M. (2018). Evaluating Level of Understanding in Calculus Foundation Course (Smn3013) among Bachelor of Mathematics Education Students.

International Journal of Academic Research in Business and Social Sciences, 8(10), 1333-1348.

Copyright: (c) 2018 The Author(s)

Published by Human Resource Management Academic Research Society (www.hrmars.com)

This article is published under the Creative Commons Attribution (CC BY 4.0) license. Anyone may reproduce, distribute, translate and create derivative works of this article (for both commercial and non-commercial purposes), subject to full attribution to the original publication and authors. The full terms of this license may be seen

at: http://creativecommons.org/licences/by/4.0/legalcode

Vol. 8, No. 10, 2018, Pg. 1333 - 1348

http://hrmars.com/index.php/pages/detail/IJARBSS

JOURNAL HOMEPAGE

Full Terms \& Conditions of access and use can be found at http://hrmars.com/index.php/pages/detail/publication-ethics 


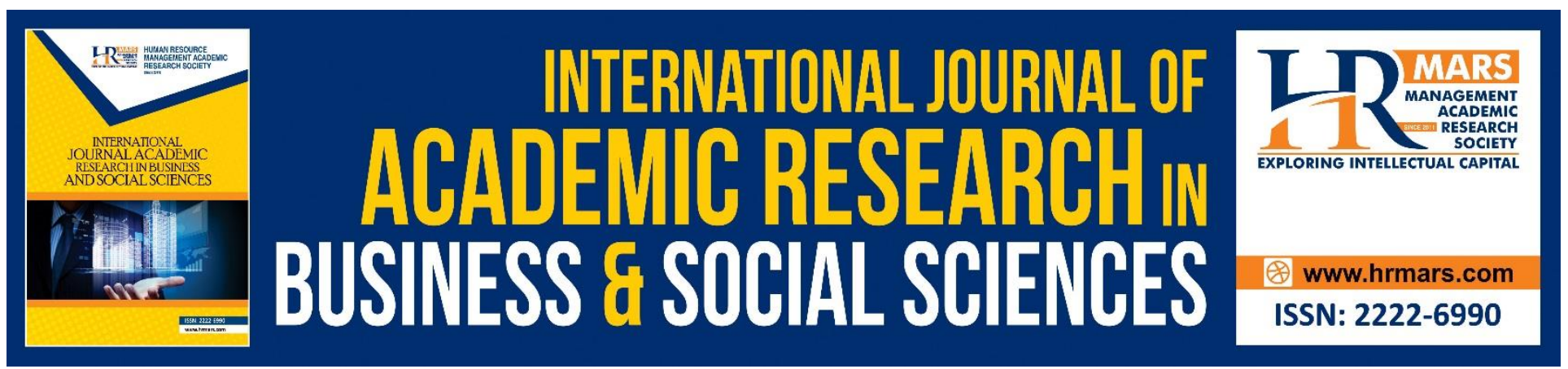

\title{
Evaluating Level of Understanding in Calculus Foundation Course (Smn3013) among Bachelor of Mathematics Education Students
}

\author{
Siti Rahaimah Ali, Nor' ain Tajudin, Nur Amalina Ahmad and \\ Norazlin Mohd Rusdin
}

Fakulti Pembangunan Manusia, Universiti Pendidikan Sultan Idris, 35900 Tanjong Malim, Perak, Malaysia.

\section{ABSTRACT}

This study discusses on evaluating Level of Understanding of Calculus Foundation base on Level of Numeracy Understanding Model (LNUM) among Bachelor of Mathematics Education students. There are four levels used in this model which consist of de-coding, meaning-making, using and analysing. This study was carried out by applying quantitative research methodology where interviews were implemented to collect data. This study has involved 30 students of Bachelor of Mathematics Education program at Sultan Idris Education University. The respondents were chosen through random sampling. In this study, respondents were assessed by using questions for the topics in Calculus Foundation (SMN3013) where it is a compulsory for the students to take this course in Semester 1. Analysis on answer scripts collected from the respondents show that majority of the respondents have achieved Level of Analysis well for the most of topics in Calculus Foundation. By using this model, students know their level of understanding for each topic in Calculus Foundation and able to identify their weaknesses. Furthermore, students can apply this model in solving problem involving calculus or other subjects in real life situations.

Keywords: Calculus Foundation, Mathematics Education, Level of Numeracy Understanding Model

\section{INTRODUCTION}

According to Buku Panduan Akademik Program ljazah Sesi 2016/2017 focus on Bachelor of Mathematics Education Program, it is a compulsory for the students to enrol in subjects related to mathematics. In this study, a subject was chosen to be developed as instrument in determining students' Level of Understanding base on LNUM. The chosen subject was one of the subjects offered in the First Semester with three (3) credits hour that is Calculus Foundation (SMN3013).

Calculus Foundation course discuss on History of Calculus, Concepts of Limit, Continuity, Differential, Polynomial, Exponential, Logarithm, Trigonometry, Proportion and Integration with One Variable Function. LNUM is a model that consist of four Level of Understanding namely (1) De-coding; 
(2) Meaning-making; (3) Using and (4) Analysing. This LNUM enable students to determine they are at which level for each mathematics problem they have solved. The instrument for observing and identifying the level of understanding among the students continuously is not available yet. Mastering the understanding at the early stage will help the students to understand the next learning process. This LNUM was built and applied in order to assist lecturer and students to determine the students' Level of Understanding in any course offered by the university.

Each level of LNUM has certain features that can recognize whether students really understand the courses they have taken during their first degree study in UPSI. LNUM was created in purpose to identify students in UPSI in specific and other universities in this country in to achieve the targeted level of understanding in general. Appropriate with challenging education policy nowadays, this model is able to identify each student's Level of Understanding for the courses offered.

\section{LITERATURE STUDY}

The framework of LNUM comprises four levels namely De-coding, Meaning-Making, Using, and Analysing (Ali, 2014). This model framework was built and adapted with the goal to determine level of understanding of the students especially those in Bachelor of Mathematics Education program.

LNUM emphasized on four levels where each of the levels has certain features that should be achieved by each student. When a student has achieved all the Levels of Numeracy Understanding, we can conclude that he/she has completely achieved the Level of Understanding for Calculus Foundation course. This model possesses a number of important elements in developing the understanding among the students. The important elements are:

i. Provide chances for the students to understand concept of Calculus Foundation and understand the context before trying to understand more complex thinking.

ii. Provide opportunities to explore with others such as in pairs, groups or whole class discussion where different opinions can be collected.

iii. Provide chances to the students to create something by using their new knowledge, especially in clarify their work to peer, and as a preparation for examination (Watson, 2017).

By using LNUM, students can generate ideas and relates the ideas in attempt to solve the give problems (Ludlow, 2014). LNUM can be used as a checklist by lecturers or students to see the understanding of a topic which has been delivered and explore other types of thinking. Students can analysis the questions given. LNUM ease the students to release each of their thinking and apply them in daily life (Ali \& Idris, 2013). The checklist provides questions as listed below:

a) What thinking has been used?

b) What other thinking should be explored?

c) What will happen during questions analysis?

By applying this model, a researchers get chance to see level of thinking among the students in solving problem which involve Calculus Foundation according to their level of understanding towards all topics in Calculus by using various calculation methods with LNUM as a guideline. This 
model encourages students to contribute their ideas without restriction. As a result, this model can guide students to think of various strategies in solving problems involving Calculus Foundation base on the levels suggested in this model. Without certain rules and regulations in solving problems involving Calculus Foundation, students are promoted to think logically, mathematically and able to possess well reasoning skills. Unconsciously, students will increase their ability to adapt the understanding in real life. A student is assumed as know calculus when he/she has confidence in selecting and using mathematics that they have learned in school to real world problems or issues (Education Queensland, 2007 in Awi, 2015).

Understanding number and skill in estimation are the addition to the procedures fluency in exploring arithmetic process and should not focus only on getting the correct answer (Ginsburg, 2008). This statement shows that at this understanding level, students not only focus on certain problem solving strategy for any problem involving Calculus Foundation. In most situations, students always think how to get the correct answer compare to find connection and reason by using various methods on how to solve a mathematics problem. This condition will retard students from thinking in wide scope and focus only on one method of solving mathematics problem. If students possess good concept understanding, students should be able to understand mathematical ideas in various contexts. Furthermore, it enables students to connect new ideas with the previous to form an effective solution for any calculus problem.

Calculus Foundation has variety of strategies that can be used to solve a problem. If students are expose to drill technique which encourage them to memorize, students will face difficulties when there are trying to apply the concepts of calculus in daily life situations. This condition may cause difficulties for them to see calculus concepts in real life. Consequently, students will practice procedural understanding in their learning where they carry out works or operations without understand the reasons (Seow \& Tan, 2010). However, LNUM emphasizes on calculating process which needs students to know and think how, why and what the most appropriate procedures that can be used to solve any problem given. By adapting this model, students build their confidence and trained to defend ideas to make sure they know what they have said. Calculating skill can be built from confidence and competency in using numbers and think mathematically in daily life, for examples able to estimate, identify probability, deal with different choices, make the best decision and choose the best skill to deal with and solve problems or situations (National Numeracy, 2013). With the self-confidence, students may increase self-braveness in giving explanation for every action or decision taken in solving mathematics problems. Besides that, confidence in understanding calculus will assist individual to answer Calculus Foundation questions effectively.

The framework of this model also provide chances for students to learn in constructivism setting which involve the connection of new knowledge with the previous one, build their own understanding, and make new meaning. Constructivism is a principle that students build their own knowledge or concept actively base on previous knowledge and experience. In this process, students will adapt knowledge they receive with their previous knowledge to build new knowledge (Malaysia Ministry of Education, 2011). According to LNUM framework, students will develop their 
understanding in learning calculus through their environment. Behaviour base on numeracy that necessary for situation management or problem solving can be created via mathematics ideas which can be represented in many ways (PIAAC, i.e., OECD Survey of Adult Skills, 2012 in Gal, 2016). This will help students develop their intelligence so that they will be able to make decision that harmonise from social and economy perspective and apply in daily life. Related to that, the model offers an alternative to help students with different capability in mathematics to be able in solving problems involving Calculus Foundation more effectively.

Students' understanding regarding to mathematics concepts influenced by the way of lessons representation and teaching methods. In this context, LNUM has been framed to overcome the problem of understanding calculus among the students. As a result, teachers should not emphasize on mathematics concepts repeatedly which more to memorize techniques on the process of mathematics problem solving. Furthermore, in this model students need clarification to understand questions and will be more effective mathematical reasoning. Without mathematical understanding, students are unable to generate more accurate ideas and will decrease students' interest towards mathematics and weak in applying numeracy concepts in real context.

\section{CONCEPTUAL FRAMEWORK}

According to earlier discussion, LNUM has 4 levels consist of De-coding, Meaning-Making, Using, and Analysing. Explanations of each level in this model are as following

\section{Level 1: De-coding}

Decoding is the first level should be mastered by the students. At this level, students should read the problem or question carefully and repeat the reading for a few times if necessary to solve the problem or question. Students should understand what they have read. All the information in the questions will guide students to solve the problem. At this level too, students make a list of given facts or information and explain them, identify important phrases and identify information with indirect meaning. Students should be able to state mathematical terminology used.

By embedding this process, students will contribute ideas in diversity of views regarding to calculus. This process can be done individually or by involving the whole class. Students must be prepared to contribute ideas in order to receive more new ideas from them. It will encourage students to recall what they have learned while generating new ideas in solving any problem involving calculus. After that, students were asked to share their own opinion during brainstorming session. This situation may create an idea which is relevant for the students base on their understanding. It shows that students are able to connect and share the ideas they are thinking of. Besides that, students can state the main process and procedure in calculus. For example, students state the operation involved in solving a problem given. At this level, students understanding on question and procedure will generate new ideas regarding to calculus. This will provide synchronisation to previous knowledge after students have going through this level. It also encourages them to explain how to get certain basic facts before solving any problem occur. 
At this level, students will make transformation in thinking by changing problem statement into representation form such as number and symbol. Representations are pure knowledge ones may create base on previous knowledge which has been built from pragmatic knowledge, representation created immediately (Staffe, 2009). This situation visualizes understanding Calculus Foundation concept as a result of what they have learned and what they show. Students also able to represent their understanding on calculus concept into the form they understood. This representation has been done repeatedly base on their experience. For example, students represent knowledge on calculus and so on.

\section{Level 2: Meaning-making}

At this level, students are able to explain how to derive the basic facts of Calculus Foundation which comprising History of Calculus, Concepts of Limit, Continuity, Differential, Polynomial, Exponential, Logarithm, Trigonometry, Proportion and Integration with One Variable Function. For example, explaining a question involving basic calculation by knowing and explaining the operation used to solve the problem. Students are able to understand the problem and explain the meaning of the problem by using their own words. During this process, students should consider a few matters such as study all the factors given, thinking of similar problem, transfer words of problem into number sentence and record planning strategy. Besides that, students should be able to explain the process and procedure used to solve a question and match the mathematical concepts after reading the question given. Students also able to meaning making at their own during brainstorming session and generate relevant ideas base on their understanding.

Students able to recognize the synchronization of concepts inter-topic and understand the main ideas which are needed to find the answer. Besides that, students know how to get mathematics basic facts and how mathematics concepts are related to each other according to their understanding toward the question given. For that reason, pupils should be able to clarify the earlier thinking, ideas and query on a topic, deeply. By this feature, they able to generate new ideas which are correspond to the previous thinking on a topic. At this level, students are exposed to a method of collecting different data and make a clear and meaningful conclusion in order to explain it accurately and systematically. In other word, students able to conclude what operation should be applied to get the answer.

This Meaning-Making Level also promotes students to think about a problem, question or topic and then state their views. For individual Calculus Foundation problem solving, lecturer can ask students in certain time allocated to think about a question or issue and share their opinions with their classmates. Meaning making also can be done by implementing activities involving small groups and for further they conclude their ideas for the whole class. This will promote the synchronization of concepts understanding through argument and active explanation because students listen and share ideas to understand various perspectives.

The result from meaning making, students can conclude what operation should be applied after the first level has been completed successfully. For the activities that involve small groups, 
students constituently present their opinions, listen with attention and asking questions to each other. This is one of the ways to make sure the students listen to each other and ask students to clarify their findings to their friends. Students will be able to assume that the way of collecting data are differ to each other and can be concluded in a clear and systematic ways

At this level too, students can match the thinking on problems in questions or topics and after that they state their opinion. This will increase their understanding by arguing and sharing ideas from various perspectives to solve numeracy problems. Students also able to match mathematical concepts base on knowledge they gained. At this level, students able to determine and explain the operation will be used to gain data according to the questions given. When a question is given, students should able to assume what kind of data they will obtain from a question. Students will match their thinking about the questions with the topics they have learned. Here, they will state their opinion and contribute ideas through various perspective whether in number, calculation, measurement, shape and space and statistics too. Students will also predict the operation will be used to solve a question given.

\section{Level 3: Using}

Using Level is the third level after students passed through Meaning-Making Level. At this level, students need to carry out strategy they have plan in correct ways to get accurate solution. Students need to decode and process the information they already know. This level is the most difficult one since students need to use and connect all information they know with the concept, facts or formula and calculate accurately. When information is gained, students able to solve the data they found in the question and carry out work to solve the problem according their understanding. Solutions carried out by students are depending on their creativity.

At this level, students are smart to determine the most appropriate procedures in understanding calculus solution and gain the important facts and concepts of calculus to solve a problem. Questions or texts provide visualisation of understanding and students apply different calculus concept which is suitable with the questions given. As a result, students will apply the data by making assumption, develop model, carry out research, imagine a scenario or create a concept map to solve a problem. Students also able to relate calculus concepts in daily life, for example time exchange concept. Students able to choose the most appropriate procedures to be applied according to type of solution for a question. Students' capability in solving certain question, has become the key that shows whether a student master a concept or procedure in calculus or not. At this Using Level, students able to solve a question when they understand the concept and procedures in problems involving calculus. Students able to relate concept of calculus in their daily live and able to choose procedure which is suitable with the question.

Students' ability in solving a problem indicates whether they are able to master a concept or understanding in numeracy. Students also able to determine whether a principle is appropriate to be used in solving new problem by providing reason concern with decision they have made. Students are able to give reasons and justification for the decision they have taken when they are trying to 
solve a new question by using the principle they have learned. Students can determine how appropriate a concept or principle to be used in solving new problem by giving acceptable reason and base on the facts of calculus concept. Here, students are smart enough to consider the information or data to be applied in solving any problem given.

Study shows that students cannot reach Using Level for a problem unless the already go through De-coding and Meaning-Making process. For example, students are unable to solve a problem spontaneously unless they already know the basic operations. This is because they assume that new problem is totally different because of there is changing in it basic calculation. This study finding shows that students unable to perfectly decode the information of Calculus Foundation. Hence, students are suggested to practice to previously make representation before get through Using Level.

\section{Level 4: Analysing}

At this level, students prove mathematics concepts and procedures they have used and should be able to according mathematics facts to support their answer. Students able to determine the relationship between the proofs with the answer they provided where students should prove every answer by using appropriate mathematics concepts they have applied. This includes making reasonable assumption and gain different views from various mathematics concepts.

The purpose of this Analysis Level is to see students' thinking, where they get opportunities to develop good inquiry that can generate thinking and investigate topics which are connect to each other. Students also able to elaborate procedures they used base on facts and proof given. This will help students to brainstorm in various questions in certain topics and understand why they answer in that way. The purpose of deeply ask interesting questions are to overcome difficulties and deepness of a topic and give concrete arguments. So, through variety of brainstorms and arguments on a topic or question given, a lot of information can be gained about the topic and answer for the question can be derived. This action will born students that smart in arguing about mathematics concepts they have used.

Besides that, students able to differentiate the logic of a number of assumptions and they are encouraged to be responsible toward their proof and argument. This may increase their motivation to do investigation when they are answering a question. At this point, students can learn new concept or topic and this will help them to obtain the latest information regarding to the topic they learn. This Analysis Level can be used during learning session as a method to stimulate curiosity among the students. Analysis Level also can be used at the end of a topic as a method for students to show how the knowledge they have obtained about a topic can help them to ask more interesting questions and able to argue.

At this level, students should brave enough to make decision concern with a question or learning topic. They must believe and confident with their answer when they are solving a question because it is necessary for them to make sure all the facts and concepts they have used in analysing 
a question are correct and accurate. They should able to prove the concepts or facts used can support the answer they have given. Students able to identify the connection among the logic proofs and able to argue about a fact or concept used to make sure it is correspond with the answer. At this level, students make decision base on reliable proof. Students also confident with mathematics concepts and terminology they have used and ensure all the facts and concepts they need to use in analysis process.

\section{OBJECTIVE OF STUDY}

This study was carried out to identify the level of understanding in Calculus Foundation base on level of calculation achieved by the students of Bachelor of Mathematics Education. In this study, researchers also interested to evaluate students' level of understanding regarding to calculation they have implemented according to topics in Calculus Foundation and see the effects on students' achievement in Calculus Foundation. The researcherss found the relevant data by refering these three research questions:

i. What are the Levels of Understanding in Calculus Foundation among Bachelor of Mathematics Education students?

ii. What are the Levels of Understanding in Calculus Foundation according to topic among Bachelor of Mathematics Education students?

\section{METHODOLOGY}

\section{RESEARCH DESIGN}

This study applied quantitative design in collecting data related to current Level of Understanding among Bachelor of Mathematics Education in Calculus Foundation course.

\section{TARGET GROUP}

30 students of Sultan Idris Education University, Tanjung Malim, Perak have participated in this study. Respondents are students of Bachelor of Mathematics Education from Faculty of Science and Mathematics. Random sampling technique has been applied to determine the respondents out of all the students in that course. This sampling technique was applied to get sample that can represent the students of this university.

\section{PROCEDURE}

In the implementation of this study, there are three phases have been work out namely first phase, researchers provided guidance about understanding numeracy module. In the next second phase, data collection proses was carried out where researchers test the module by giving tasks related to topics in Calculus Foundation to the respondents. The third phase was a phase of analysing the data and conduct an interview with four out of 30 respondents to make sure and reinforce the finding of this study toward their level of understanding based on calculation they have done in solving mathematics problem given. 
INTERNATIONAL JOURNAL OF ACADEMIC RESEARCH IN BUSINESS AND SOCIAL SCIENCES

Vol. 8, No. 10, Oct. 2018, E-ISSN: $2222-6990$ (C) 2018 HRMARS

\section{DATA ANALYSIS}

This study used descriptive statistic like percentage, mean and median to provide information about level of understanding among the students of Bachelor of Mathematics Education in Calculus Foundation.

\section{FINDING AND DISCUSSION}

There were two questions emphasized in this research as the following:

Research question 1: What is the level of understanding in Calculus Foundation among Bachelor of Mathematics Education students

The finding of this study may answer the research question on identifying Level of Understanding among Bachelor of Mathematics Education students. The following graph shows Level of Understanding in Calculus Foundation among Bachelor of Mathematics Education students.:

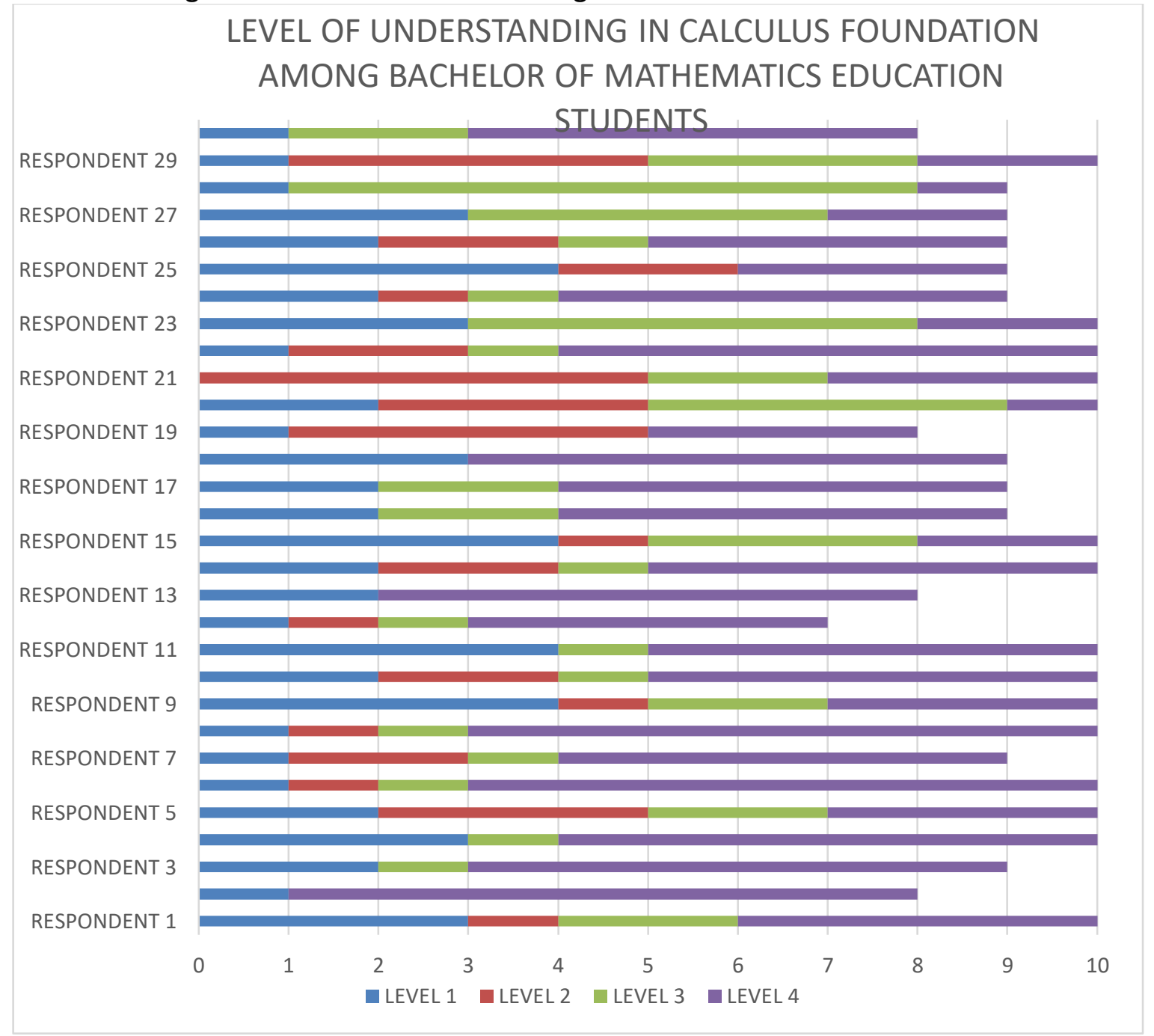

Graph 1: Level of Understanding in Calculus Foundation 
INTERNATIONAL JOURNAL OF ACADEMIC RESEARCH IN BUSINESS AND SOCIAL SCIENCES Vol. 8, No. 10, Oct. 2018, E-ISSN: 2222-6990 ㄷ 2018 HRMARS

Graph 1 above shows level of understanding in Calculus Foundation for each respondent in this study. The data shows 15 respondents successfully answer all the questions given related to Calculus Foundation and each question show students' level of understanding. In the other hand, 15 respondents were failed to answer the questions related to Calculus Foundation in allocated time. Data from Graph 1 can be concluded to determine level of understanding in Calculus Foundation for each students of Bachelor of Mathematics Education as shown in the Table 1 below.

Table 1: Number of Students Based on Level of Understanding in Calculus Foundation

\begin{tabular}{|c|c|c|c|c|}
\hline \multirow[b]{2}{*}{ Respondent } & \multicolumn{4}{|c|}{ Level of Understanding in Calculus Foundation } \\
\hline & $\begin{array}{c}1 \\
\text { De-coding }\end{array}$ & $\begin{array}{c}2 \\
\text { Meaning-Making }\end{array}$ & $\begin{array}{c}3 \\
\text { Using }\end{array}$ & $\begin{array}{c}4 \\
\text { Analysis }\end{array}$ \\
\hline $\begin{array}{l}\text { Respondent } \\
1\end{array}$ & & & & $\checkmark$ \\
\hline $\begin{array}{l}\text { Respondent } \\
2\end{array}$ & & & & $\checkmark$ \\
\hline $\begin{array}{l}\text { Respondent } \\
3\end{array}$ & & & & $\checkmark$ \\
\hline $\begin{array}{l}\text { Respondent } \\
4\end{array}$ & & & & $\checkmark$ \\
\hline $\begin{array}{l}\text { Respondent } \\
5\end{array}$ & & $\checkmark$ & & \\
\hline $\begin{array}{l}\text { Respondent } \\
6\end{array}$ & & & & $\checkmark$ \\
\hline $\begin{array}{l}\text { Respondent } \\
7\end{array}$ & & & & $\checkmark$ \\
\hline $\begin{array}{l}\text { Respondent } \\
8\end{array}$ & & & & $\checkmark$ \\
\hline $\begin{array}{l}\text { Respondent } \\
9\end{array}$ & $\checkmark$ & & & \\
\hline $\begin{array}{l}\text { Respondent } \\
10\end{array}$ & & & & $\checkmark$ \\
\hline $\begin{array}{l}\text { Respondent } \\
11\end{array}$ & & & & $\checkmark$ \\
\hline $\begin{array}{l}\text { Respondent } \\
12\end{array}$ & & & & $\checkmark$ \\
\hline $\begin{array}{l}\text { Respondent } \\
13\end{array}$ & & & & $\checkmark$ \\
\hline $\begin{array}{l}\text { Respondent } \\
14\end{array}$ & & & & $\checkmark$ \\
\hline $\begin{array}{l}\text { Respondent } \\
15\end{array}$ & $\checkmark$ & & & \\
\hline
\end{tabular}


INTERNATIONAL JOURNAL OF ACADEMIC RESEARCH IN BUSINESS AND SOCIAL SCIENCES Vol. 8, No. 10, Oct. 2018, E-ISSN: 222 2-6990 @ 2018 HRMARS

\begin{tabular}{|c|c|c|c|c|}
\hline $\begin{array}{l}\text { Respondent } \\
16\end{array}$ & & & & $\checkmark$ \\
\hline $\begin{array}{l}\text { Respondent } \\
17\end{array}$ & & & & $\checkmark$ \\
\hline $\begin{array}{l}\text { Respondent } \\
18\end{array}$ & & & & $\checkmark$ \\
\hline $\begin{array}{l}\text { Respondent } \\
19\end{array}$ & & $\checkmark$ & & \\
\hline $\begin{array}{l}\text { Respondent } \\
20\end{array}$ & & & $\checkmark$ & \\
\hline $\begin{array}{l}\text { Respondent } \\
21\end{array}$ & & $\checkmark$ & & \\
\hline $\begin{array}{l}\text { Respondent } \\
22\end{array}$ & & & & $\checkmark$ \\
\hline $\begin{array}{l}\text { Respondent } \\
23\end{array}$ & & & $\checkmark$ & \\
\hline $\begin{array}{l}\text { Respondent } \\
24\end{array}$ & & & & $\checkmark$ \\
\hline $\begin{array}{l}\text { Respondent } \\
25\end{array}$ & $\checkmark$ & & & \\
\hline $\begin{array}{l}\text { Respondent } \\
26\end{array}$ & & & & $\checkmark$ \\
\hline $\begin{array}{l}\text { Respondent } \\
27\end{array}$ & & & $\checkmark$ & \\
\hline $\begin{array}{l}\text { Respondent } \\
28\end{array}$ & & & $\checkmark$ & \\
\hline $\begin{array}{l}\text { Respondent } \\
29\end{array}$ & & $\checkmark$ & & \\
\hline $\begin{array}{l}\text { Respondent } \\
30\end{array}$ & & & & $\checkmark$ \\
\hline Total & 3 & 4 & 4 & 19 \\
\hline
\end{tabular}

Table 1 shows level of analysis is the Level of Understanding in Calculus Foundation with the highest number of respondents, 19 while Level of Understanding in Calculus Foundation with the lowest number of students is level of decoding with only 3 respondents. Level of Understanding in Calculus Foundation has been determined based on the frequency of Level of Understanding obtained for each question. Hence, it is clearly shows that many students are able to answer Calculus Foundation questions to the fourth level which is Level of Analysis. Frequencies for Level of De-coding are low in answering calculus questions. It is happened due to students are unable to understand the questions and decided the most appropriate calculation method to solve the questions.

Research question 2: What is the level of understanding according to the topics of Calculus Foundation among Bachelor of Mathematics Students? 
Graph 2 below shows level of understanding among the students for the topics in Calculus Foundation

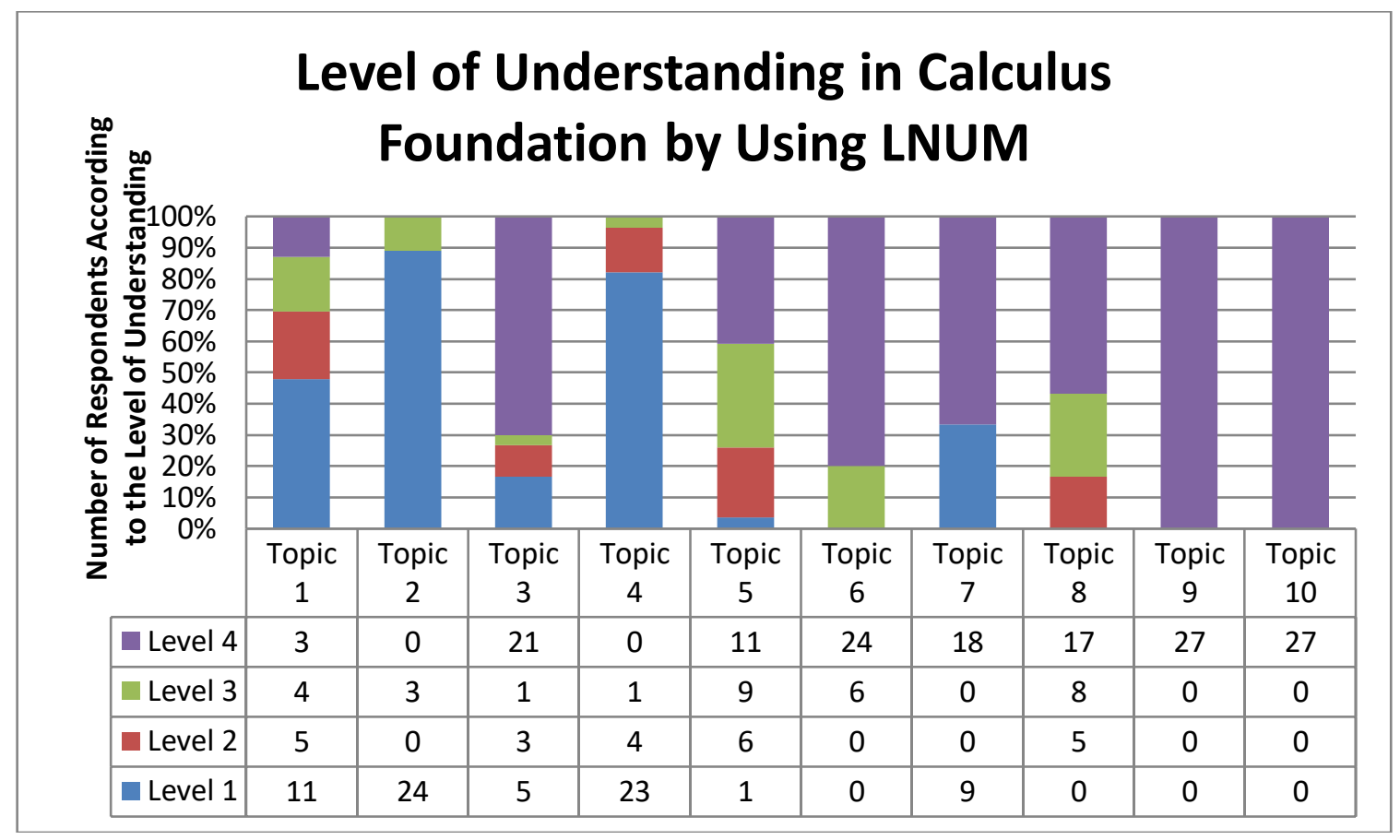

Graph 2: Level of Numeracy Understanding

Graph 2 above shows Level of Understanding for each topic in Calculus Foundation for Bachelor of Mathematics Education in UPSI. Base on the graph, easier for the students to answer calculus questions by using LNUM for the last topics which are topic 3 and the topics in the range from 5 to 10. Can be concluded here that majority of the students are able to answer questions well till level 4 which is level of analysis for seven topics in Calculus Foundation. Based on interview with four respondents, researchers can see that level of understanding among the students were influenced by their previous knowledge about calculus concepts where they were able to give explanation clearly for the calculation they have carried out in writing. This matter can be proved by interview session involving four respondents to evaluate and understand how respondents think during solving calculus questions given to them. During the interview, all the respondents were able to explain clearly to show their Level of Understanding in answering the question in detail. In the interview session, respondent were asked to explain each calculation they have work out in order to determine level of understanding of the students accurately. Recording of the interview session was one of the resources that support the finding of this study.

By referring to Graph 3, data of this study shows that many students have achieved Level of Understanding at level 1 which is Level of De-coding for Topic 1 about concepts of limit and Topic 4 which is about differentiate. Both of these topics show difficulties of the students to achieve Level 4. This was due to the highest Level of Understanding students were able to achieve for these topics only at Level 3, Level of Using. The finding represented in Graph 1 shows that many students were 
INTERNATIONAL JOURNAL OF ACADEMIC RESEARCH IN BUSINESS AND SOCIAL SCIENCES

Vol. 8, No. 10, Oct. 2018, E-ISSN: 2222-6990 @ 2018 HRMARS

excellent since they able to achieve Level of Using and Level of Analysis. However, there were some answers and calculation given by the respondents were incorrect and from the interview, respondents able to explain the calculation they have work out in clear and confidence.

Table 2 below shows data related to frequency and percentage of Bachelor of Mathematics Education students' performance in Calculus Foundation topics.

Table 2: Frequency and Percentage of Level of Numeracy Understanding in Calculus

\begin{tabular}{|c|c|c|c|c|c|c|c|c|}
\hline \multirow{3}{*}{ Topic } & \multicolumn{8}{|c|}{ Level of Numeracy Understanding } \\
\hline & \multicolumn{2}{|c|}{$\begin{array}{c}1 \\
\text { De-coding }\end{array}$} & \multicolumn{2}{|c|}{$\begin{array}{c}2 \\
\text { Meaning- } \\
\text { Making }\end{array}$} & \multicolumn{2}{|c|}{$\begin{array}{c}3 \\
\text { Using }\end{array}$} & \multicolumn{2}{|c|}{$\begin{array}{c}4 \\
\text { Analysis }\end{array}$} \\
\hline & $f$ & $\%$ & $f$ & $\%$ & $f$ & $\%$ & $f$ & $\%$ \\
\hline Topic 1 & 11 & 36.7 & 5 & 16.7 & 4 & 13.3 & 3 & 10.0 \\
\hline Topic 2 & 24 & 80.0 & 0 & 0 & 3 & 10.0 & 0 & 0 \\
\hline Topic 3 & 5 & 16.7 & 3 & 10.00 & 1 & 3.33 & 21 & 70.0 \\
\hline Topic 4 & 23 & 76.7 & 4 & 13.3 & 1 & 3.33 & 0 & 0 \\
\hline Topic 5 & 1 & 3.33 & 6 & 20.0 & 9 & 30.0 & 11 & 36.7 \\
\hline Topic 6 & 0 & 0 & 0 & 0 & 6 & 20.0 & 24 & 80.0 \\
\hline Topic 7 & 9 & 30.0 & 0 & 0 & 0 & 0 & 18 & 60.0 \\
\hline Topic 8 & 0 & 0 & 5 & 16.7 & 8 & 26.7 & 17 & 56.7 \\
\hline Topic 9 & 0 & 0 & 0 & 0 & 0 & 0 & 27 & 90.0 \\
\hline $\begin{array}{c}\text { Topic } \\
10\end{array}$ & 0 & 0 & 0 & 0 & 0 & 0 & 27 & 90.0 \\
\hline Total & 73 & 26.4 & 23 & 8.3 & 32 & 11.6 & 148 & 53.6 \\
\hline
\end{tabular}

There are ten topics in Calculus Foundation which consist of History of Calculus (Topic 1), Concepts of Limit (Topic 2), Continuity (Topic 3), Differential (Topic 4), Polynomial (Topic 5), Exponential (Topic 6), Logarithm (Topic 7), Trigonometry (Topic 8), Proportion (Topic 9) and Integration with One Variable Function (Topic 10). According to the analysis as shown in Table 1, it was found that the highest performance was at analysis level with $90 \%$ for Topic 9 and Topic 10. According to this finding, there are $10 \%$ of the students to achieve any level of understanding for these two topics. This data shows that most of the students were easy to answer questions in Proportion and Integration compare to other topics in this Calculus Foundation. The following are the conversation transcripts that show students' performance in describing their answer for question number 27 about Integration:

Researchers : The next question about integration. Aida, what do you understand about this question?

Respondent : What I understand about this question, it is about to find the area of function and it gives an equation with $x$ value start from -3 to 0 . 
INTERNATIONAL JOURNAL OF ACADEMIC RESEARCH IN BUSINESS AND SOCIAL SCIENCES

Vol. 8, No. 10, Oct. 2018, E-ISSN: 2222-6990 ㄷ 2018 HRMARS

Researchers : So, how can we know the area for the equation with the $x$ values given?

What you have use, Aida?

Respondent : I use integration. Integrate the equation give, $x^{2}+3$.

.When it is integrated, we will get $\frac{x^{3}}{3}+a x$.

Researchers : Why did in the working steps, you use $\frac{x}{3}$. Can you explain? Tell me about it.

Respondent : This one, when $x^{2} d x$. Then, integrate the value it will add 1 and it gets 3. After that, $x^{3}$ this 3 I divided by 3.

Researchers : Why did you divide it by 3 ?

Respondent : This is the way it works. We will divide the upper value.

Researchers : How to solve the equation? What do you do with the $x$ value?

Respondent : We just replace the value in the equation. Then, subtract again in the equation. We substitute with 0.

Researchers : From the equation, why did you use subtraction? Why subtraction and not addition?

Respondent : Because to find the area.

Researchers : So, what is the total area you get?

Respondent : The area I get is 18 .

Researchers : Is there is other way? Maybe you can shade or draw a graph? Or there is other way?

Respondent : I am not sure about the other way.

Researchers : So, this is the only way to solve the question?

Respondent : Yes, it is.

Base on the conversation above, it is clearing shows that students were able to give explanation precisely regarding to the question asked based on LNUM, very well and full of confidence. It is shows that students understand the question's needs and successfully think the most appropriate calculation way to solve it.

\section{CONCLUSION}

Level of Understanding Numeracy Model (LNUM) is the way to help students in understanding questions from various topics in Calculus. Through this model, students are able to identify the questions and in further give ideas start from Level of De-coding to Level of Analysis for each question given, more effectively. This study is carried out to prove that majority of students are able to achieve till Level of Analysis for 2/3 topics in Calculus Foundation. Related to the point, LNUM can encourage students to identify their weaknesses in understand the question and in further students will able to apply this model in solving daily life problems.

\section{Corresponding Author}

Siti Rahaimah Ali, Fakulti Pembangunan Manusia, Universiti Pendidikan Sultan Idris 35900 Tanjong Malim, Perak, Malaysia, Email: siti.rahaimah@fpm.upsi.edu.my 
INTERNATIONAL JOURNAL OF ACADEMIC RESEARCH IN BUSINESS AND SOCIAL SCIENCES

Vol. 8, No. 10, Oct. 2018, E-ISSN: 222 2-6990 @ 2018 HRMARS

\section{References}

Othman, A. J., Norzan, N., Darusalam, G., \& Siraj, S. (2011). Cabaran Guru Program LINUS Dalam Pengajaran dan Pembelajaran Bahasa. Fakulti Pendidikan, Universiti Malaya.

Awi, A. (2015). Tahap Numerasi Dan Strategi Penyelesaian Masalah Dalam Bidang Nombor Bagi Pelajar Lepasan Menengah. Universiti Sains Malaysia.

Gal, I. (2016). Assessment of Adult Numeracy Skills. University of Haifa.

Kementerian Pendidikan Malaysia. (2001). Pembelajaran secara Konstruktivisme.

Ginsburg, L. (2008). Designing Instruction with the Components of Numeracy in Mind. World Education.

National Numeracy (2013). Essentials of Numeracy For All. Retrieve from: https://www.nationalnumeracy.org.uk/sites/default/files/essentials_of_numeracy_downloa d_v2.pdf

Seow, S. H. \& Tan, S. K. (2000). Pendekatan Mengajar Matematik Sekolah Rendah. Petaling Jaya : Alpha Sdn. Bhd.

Ali, S. R (2014) Tesis Phd: Analisis Kefahaman Numerasi Sekolah Rendah. UPSI

Ali, S. R \& Idris, N. (2013). A Model to Indentify the level of Numeracy Understanding of primary school. International Journal of Computer Application, 67(5). 